M олекулярный мониторинг и определение чувствительности $N$. gonorrhoeae к антимикробным препаратам как инструменты контроля над распространением гонококковой инфекции в Архангельской области

\author{
К.В. Барышков², Н.В. Фриго ${ }^{1}$, В.С. Соломка ${ }^{1}$
}

1 ФГБУ «Государственный научный центр дерматовенерологии и косметологии» Минздрава России 107076, Москва, ул. Короленко, д. 3, стр. 6

${ }^{2}$ ГБУЗ АО «Архангельский клинический кожно-венерологический диспансер» 163045 , г. Архангельск, пр. Сибиряковцев, д. 2, корп. 1

\footnotetext{
Изучена чувствительность 203 штаммов N. gonorrhoeae, полученных от больных гонококковой инфекцией на территории Архангельской области, к антимикробным препаратам (АМП). Установлено, что тенденции распространения штаммов N. gonorrhoeae, не чувствительных к АМП, совпадают с общероссийскими. Препаратом выбора для лечения гонококковой инфекции на территории области остается цестриаксон. На территории области отмечены признаки формирования устойчивости штаммов N. gonorrhoeae к данному АМП.

С использованием методов молекулярной эпидемиологии (секвенирования и филогенетического анализа) исследован 51 штамм N. gonorrhoeae, полученный от больных гонококковой инфекцией в 2011 г. Выявлена гетерогенность выборки штаммов N. gonorrhoeae, циркулирующих на территории Архангельской области, и высокая скорость их генетической изменчивости. Отмечено, что на территории Архангельской области регистрируются штаммы N. gonorrhoeae, уникальные для данного географического региона (доминирующие сиквенс-типы № 343, 5042, 1523, 1152, 387, 6238, 5825, 6234, а также единичные сиквенс-типы). Показана возможность использования молекулярных методов (полимеразной цепной реакции - ПЦР и секвенирования) для индивидуальной идентисрикации источников заражения и половых партнеров больных гонококковой инфекцией и осуществления эпидемиологического мониторинга. Установлены ассоциации между принадлежностью штаммов N. gonorrhoeae, выделенных от больных гонококковой инфекцией в Архангельской области, к сиквенс-типам № 343, 285, 2625, 6237 и их мультирезистентностью, что требует проведения тщательного обследования и определения тактики терапии таких пациентов.

С учетом результатов проведенных исследований разработаны рекомендации по контролю над распространением гонококковой инсрекции на территории Архангельской области.
}

Ключевые слова: гонококковая инфекция, N. gonorrhoeae, антимикробные препараты, антибиотикорезистентность, молекулярное типирование, NG-MAST, эпидемиология.

Контактная информация: kvbar@yandex.ru. Вестник дерматологии и венерологии 2013; (4): 52_62. 


\title{
Molecular monitoring and determination of $N$.gonorrboeae sensitivity to antimicrobial drugs as tools to control the propagation of gonococcal infection in the Arkhangelsk Region
}

\author{
K.V. Baryshkov², N.V. Frigo' ${ }^{1}$, V.S. Solomka ${ }^{1}$
}

${ }^{1}$ State Research Center of Dermatovenereology and Cosmetology, Ministry of Healthcare of the Russian Federation, Moscow

Korolenko str 3, bldg 6, 107076, Moscow, Russia

${ }^{2}$ Archangelsk Regional Dermatovenerologic dispansary

163045, Archangelsk city, street Sibiryakovcev 2-1

As a result of studying the sensitivity indices concerning antimicrobial drugs (AMD) for 203 strains of N. gonorrhoeae obtained from patients suffering from the gonococcal infection in the Arkhangelsk region, it was established that the trends of $\mathrm{N}$. gonorrhoeae strains propagation, which are resistant to AMD, match the trends in Russia in general. Ceftriaxone is the drug of choice to treat the gonococcal infection in the territory of the region. It was observed that $N$. gonorrhoeae strains started developing resistance to the AMD in the territory of the region.

The authors conducted a study of $51 \mathrm{~N}$. Gonorrhoeae strains obtained from patients suffering from the gonococcal infection in 2011 using molecular epidemiology methods (sequence and phylogenetic analysis). Heterogeneity in the sample of the N. gonorrhoeae strains circulating in the territory of the Arkhangelsk region as well as high rate of their genetic variability were revealed. It was noted that $N$. gonorrhoeae strains, which are unique for this geographic region (dominating sequence types No. $343,5042,1523,1152,387,6238,5825$ and 6234 as well as single sequence types), are registered in the territory of the Arkhangelsk region. The authors demonstrated the possibility to use molecular methods (PCR and sequence analysis) for individual identification of infection sources and sexual partners of patients suffering from the gonococcal infection and for the purposes of epidemiological monitoring. The authors established associations between the fact that the N. gonorrhoeae strains obtained from patients suffering from the gonococcal infection in the Arkhangelsk region belong to sequence types No. 343, 285, 2625 and 6237, and their multi-resistance, which demands a thorough examination to determine the treatment tactics for such patients.

Taking into consideration the results of these studies, the authors prepared recommendations on how to control the propagation of the gonococcal infection in the territory of the Arkhangelsk region.

Key words: gonococcal infection, N. gonorrhoeae, antimicrobial drugs, antibiotic resistance, molecular typing, NGMAST, epidemiology.

Corresponding author: kvbar@yandex.ru. Vestnik Dermatologii i Venerologii 2013; 4: 52—62. 
Гонококковая инфекция относится к числу широко распространенных социально значимых инфекций, передаваемых половым путем (ИППП). Несмотря на наблюдаемую в последние годы тенденцию к снижению, заболеваемость гонококковой инфекцией в Российской Федерации продолжает оставаться высокой [1]. В 2011 г. уровень заболеваемости гонококковой инфекцией в Российской Федерации составил 32,5 на 100000 населения.

Одной из возможных причин, способствующих нестабильности эпидемиологической ситуации и высокой заболеваемости гонококковой инфекцией, является резистентность возбудителя $N$. gonorrhoeae к антимикробным препаратам (АМП). Появление и распространение штаммов N.gonorrhoeae, устойчивых к АМП, способствуют длительному, рецидивирующему течению заболевания и развитию тяжелых осложнений (воспалительных заболеваний органов малого таза у женщин, эпидидимитов и орхитов у мужчин, развитию бесплодия у лиц обоих полов).

К числу мер противодействия распространению резистентных к АМП штаммов $N$. gonorrhoeae относятся программы мониторинга антибиотикорезистентности N. gonorrhoeae. В Российской Федерации с 2002 г. под руководством Государственного научного центра дерматовенерологии и косметологии (ГНЦДК) успешно выполняется программа мониторинга антибиотикорезистентности N. gonorrhoeae, получившая мировое признание и известная под названием RU-GASP (The Russian gonococcal antimicrobial susceptibility programme) [2-4]. Однако, несмотря на важность глобального, на уровне государств и международных организаций, планирования политики антимикробной терапии гонококковой инфекции, наиболее рациональным в настоящее время признается учет данных по антибиотикорезистентности N. gonorrhoeae и разработка рекомендаций по терапии гонококковой инфекции в конкретном географическом регионе, так как штаммы возбудителя, распространенные в определенном регионе, могут иметь свои особые, отличающиеся биологические свойства [4].

Одним из современных инструментов эпидемиологического контроля над распространением инфекционных заболеваний являются молекулярные методы типирования микроорганизмов, основанные на ПЦР и секвенировании. Данные методы дают возможность выявлять сходство и различия между штаммами бактерий одного биологического вида, выделенными от различных пациентов или из различных источников в окружающей среде, на молекулярном уровне и, в отличие от фенотипических методов типирования, позволяют проводить исследования быстро и с использованием небольшого количества бактериальной культуры [5].

Применительно к N.gonorrhoeae общепринятым в настоящее время является метод молекулярного типирования NG-MAST (Neisseria gonorrhoeae - multiantigen-sequence-typing), основанный на секвенировании фррагментов двух генов $N$. gonorrhoeae - porB гена, кодирующего белок поринового канала, и $t b p B$ гена, кодирующего трансферринсвязывающий белок. Метод обладает высокой дискриминирующей способностью, позволяет определить сиквенс-тип штамма N. gonorrhoeae, представляющий индивидуальную генетическую характеристику изучаемого штамма. Информация о сиквенс-типах N.gonorrhoeae, каждый из которых имеет свой индивидуальный номер, хранится в международной базе данных NG-MAST (http://www.ng-mast.net) и позволяет отслеживать интродукцию штаммов внутри отдельных областей одного государства и между государствами, изучать взаимосвязь гетерогенности субтипов и географического расположения региона, определять особенности передачи инфекции между половыми партнерами [6].

К настоящему времени имеются единичные публикации, посвященные изучению показателей антибиотикорезистентности и распространения молекулярных типов N.gonorrhoeae на территории Архангельской области [7]. Исследования по научному обоснованию выбора препаратов для терапии гонококковой инфекции и разработке системы мер противодействия распространению гонококковой инфекции с использованием методов молекулярной эпидемиологии на территории Архангельской области не проводились.

Цель исследования - разработка методов контроля над распространением гонококковой инфекции на территории Архангельской области с учетом определения резистентности штаммов N. gonorrhoeae к АМП и использования методов молекулярной эпидемиологии.

\section{Материал и методы}

Исследования проводились на базе ГБУЗ АО «Архангельский клинический кожно-венерологический диспансер» (АККВД) и ФГБУ «Государственный научный центр дерматовенерологии и косметологии» Минздрава России (ГНЦДК), Москва.

Для проведения исследований в течение 20062011 гг. от 203 больных Архангельской области с подозрением на наличие гонококковой инфекции было получено 203 образца биологического материала (соскобный материал слизистой оболочки уретры, цервикального канала, шейки матки, прямой кишки).

Лабораторное подтверждение диагноза гонококковой инфекции осуществлялось бактериоскопическим и культуральным методами. Полученные культуры штаммов $N$. gonorrhoeae проверялись на чистоту и правильность их идентификации с использованием тест-систем «Кристал нейссерия/гемофилис» (Бектон Диккинсон, США) и контрольного штамма из коллекции типовых культур микроорганизмов штамма N. gonorrhoeae ATCC 49226. 
После установления принадлежности микроорганизмов к виду N. gonorrhoeae методом серийных разведений в агаре определяли чувствительность возбудителя к шести АМП: пенициллину, тетрациклину, ципрофлоксацину, спектиномицину, азитромицину и цестриаксону. Оценка чувствительности N. gonorrhoeae к АМП проводилась в соответствии с критериями CLSI (Clinical and Laboratory Standards Institution) [8]; к азитромицину - в соответствии с критериями EUCAST (The European Committee on Antimicrobial Susceptibility Testing) [9]. Обработка результатов исследования антибиотикорезистентности N. gonorrhoeae осуществлялась с использованием компьютерной аналитической программы WHONET версии 5.4, в которую включены критерии интерпретации антибиотикограмм.

Для сравнительного анализа результатов определения резистентности штаммов $N$. gonorrhoeae к АМП в Архангельской области и Северо-Западном федеральном округе были использованы данные ФГБУ «ГНЦДК» Минздрава России, полученные в 2011 г. в ходе выполнения научно-исследовательской работы в рамках Федеральной целевой программы «Предупреждение и борьба с социально значимыми заболеваниями (2007-2011 гг.)» (Отчет о научно-исследовательской работе «Разработка систем прогнозирования распространения штаммов возбудителей инфекций, передаваемых половым путем (на модели N. gonorrhoeae), на территории Российской Федерации на основе методов молекулярной эпидемиологии»; Государственный контракт от 10 ноября 2011 г. № K-32-НИР/121-3).

Молекулярное типирование штаммов N. gonorrhoeae проводилось путем определения нуклеотидной последовательности генов por и tbp N.gonorrhoeae в несколько этапов: выделение ДНК N.gonorrhoeae из биообразцов (культур N.gonorrhoeae; ДНК-ЭКСПРЕСС, Литех, Россия); амплификация ДНК вариабельных участков генов por и tbp N. gonorrhoeae (метод ПЦР); детекция и визуализация продуктов амплификации ДНК генов por и tbp N. gonorrhoeae; осаждение продуктов амплисрикации ДНК генов por и tbp N. gonorrhoeae с целью получения чистого препарата ДНК; проведение ПЦР с мечеными терминирующими нуклеотидами с использованием коммерческого набора реагентов для секвенирования ДНK Big Dye Terminator v 3.1 Sequencing RR-100 (Applied Biosystems, США); осаждение продуктов ПЦР; проведение реакции секвенирования por и tbp N. gonorrhoeae на приборе 3730 Genetic Analyzer (Applied Biosystems, USA) с использованием программного обеспечения 3730 Data Collection v 3.0 и дальнейшей обработкой полученных данных в программе Sequencing Analysis 5.3.1; анализ нуклеотидных последовательностей генов por и tbp N. gonorrhoeae и их выравнивание проводились с помощью программ Vector NTI 9.1 и DNA Star Edit
Seq. и сервера ClustalW2 (http://www.ebi.ac.uk/Tools/ $\mathrm{msa} /$ clustalw2/). После получения расшифрованных нуклеотидных последовательностей генов por и tbp N. gonorrhoeae для них на основании данных, представленных в международной базе данных NG-MAST, определялись порядковые номера аллелей и сиквенстипы.

С целью выявления более или менее представительных кластеров штаммов N. gonorrhoeae, циркулирующих на территории Архангельской области, а также возможных путей их распространения был проведен фрилогенетический анализ. Анализ осуществлялся на основании сравнения выровненных последовательностей генов por и tbp N.gonorrhoeae при помощи программ AlignX из пакета программ Vector NTI 9.1.0 и программы MEGA и построения фрилогенетического дерева (дендрограммы). Дендрограмма была построена с использованием биоинформатического метода Neighborjoining, позволяющего осуществлять объединение последовательностей белков и/или ДНК (в данном случае - сиквенс-типов штаммов N. gonorrhoeae) в кластеры на основании вычисления эволюционных расстояний между парами таксонов $[10,11]$.

С использованием методов молекулярной эпидемиологии были проведены исследования: методом секвенирования 51 штамма N. gonorrhoeae, полученного из регионов Архангельской области в 2011 г., филогенетический анализ проведен для 48 штаммов N. gonorrhoeae.

Результаты определения сиквенс-типов штаммов N. gonorrhoeae из регионов Архангельской области были сопоставлены с данными ФГБУ «ГНЦДК» Минздрава России, полученными в 2011 г. в ходе выполнения НИР в рамках Федеральной целевой программы «Предупреждение и борьба с социально значимыми заболеваниями (2007-2011 гг.)» [12].

\section{Результаты и обсуждение}

Результаты изучения чувствительности штаммов N.gonorrhoeae к АМП. Результаты определения чувствительности штаммов N. gonorrhoeae, полученных из регионов Архангельской области за период 2006-2011 гг., к АМП представлены в таблице. Как следует из приведенных данных, на протяжении 2006-2011 гг. на территории Архангельской области регистрировался высокий процент штаммов N. gonorrhoeae, не чувствительных к пенициллину $(25,0-$ $61,9 \%$; в 2009 г. - 6,2\%), тетрациклину $(26,9-58,0 \%)$, ципрофрлоксацину (14,3-36,0\%; в 2008, 2009 гг. соответственно 8,0 и 6,2\%). Процент штаммов N. gonorrhoeae, циркулирующих на территории области, не чувствительных к спектиномицину, увеличился с 0-4,8\% в 2007-2006 гг. до 12,5-20,0\% в 20082011 гг. На протяжении 2010-2011 гг. отмечено существенное возрастание процента штаммов N. gonorrhoeae, не чувствительных к азитромицину (с 0-6,0\% 


\begin{tabular}{|c|c|c|c|c|c|c|c|c|c|c|c|c|c|c|c|c|c|c|c|c|c|c|}
\hline \multirow{2}{*}{$\begin{array}{l}\text { Год } \\
\text { иссле- } \\
\text { дования }\end{array}$} & \multicolumn{4}{|c|}{ Пенициллин } & \multicolumn{4}{|c|}{ Тетрациклин } & \multicolumn{4}{|c|}{ Ципрофлоксацин } & \multicolumn{4}{|c|}{ Спектиномицин } & \multicolumn{4}{|c|}{ Азитромицин } & \multicolumn{2}{|c|}{$\begin{array}{c}\text { Цеср- } \\
\text { три- } \\
\text { аксон }\end{array}$} \\
\hline & $\mathrm{R}$ & I & $\mathrm{R}+\mathrm{l}$ & S & $\mathrm{R}$ & I & $\mathrm{R}+\mathrm{l}$ & $S$ & $\mathrm{R}$ & I & $R+1$ & $S$ & $\mathrm{R}$ & I & $\mathrm{R}+\mathrm{l}$ & $S$ & $\mathrm{R}$ & I & $\mathrm{R}+\mathrm{l}$ & S & $\mathrm{R}+\mathrm{l}$ & $S$ \\
\hline $\begin{array}{l}2006 \text { г. } \\
(n=21)\end{array}$ & 14,3 & 47,6 & 61,9 & 38,1 & 19,0 & 38,1 & 57,1 & 42,9 & 14,3 & 0,0 & 14,3 & 85,7 & 0,0 & 4,8 & 4,8 & 95,2 & - & - & - & - & 0,0 & 100,0 \\
\hline $\begin{array}{l}2007 \text { г. } \\
(n=39)\end{array}$ & 7,7 & 38,5 & 46,2 & 53,8 & 20,6 & 25,6 & 46,2 & 53,8 & 25,7 & 5,1 & 30,8 & 69,2 & 0,0 & 0,0 & 0,0 & 100,0 & 6,0 & 0,0 & 6,0 & 94,0 & 0,0 & 100,0 \\
\hline $\begin{array}{l}2008 \text { г. } \\
(n=50)\end{array}$ & 14,0 & 36,0 & 50,0 & 50,0 & 30,0 & 24,0 & 54,0 & 46,0 & 6,0 & 2,0 & 8,0 & 92,0 & 2,0 & 18,0 & 20,0 & 80,0 & 4,0 & 0,0 & 4,0 & 92,0 & 0,0 & 100,0 \\
\hline $\begin{array}{l}2009 \text { г. } \\
(n=16)\end{array}$ & 0,0 & 25,0 & 25,0 & 75,0 & 6,2 & 0,0 & 6,2 & 93,8 & 6,2 & 0,0 & 6,2 & 93,8 & 0,0 & 12,5 & 12,5 & 87,5 & 0,0 & 0,0 & 0,0 & 100,0 & 0,0 & 100,0 \\
\hline $\begin{array}{l}2010 \text { г. } \\
(n=26)\end{array}$ & 3,8 & 38,5 & 42,3 & 57,7 & 23,1 & 3,8 & 26,9 & 73,1 & 15,4 & 3,8 & 19,2 & 80,8 & 4,2 & 10,2 & 14,4 & 85,6 & 15,4 & 0,0 & 15,4 & 84,6 & 0,0 & 100,0 \\
\hline $\begin{array}{l}2011 \text { г. } \\
(n=51)\end{array}$ & 12,0 & 32,0 & 44,0 & 56,0 & 42,0 & 16,0 & 58,0 & 42,0 & 32,0 & 4,0 & 36,0 & 64,0 & 6,0 & 12,0 & 18,0 & 82,0 & 16,0 & 0,0 & 16,0 & 84,0 & 0,0 & 100,0 \\
\hline
\end{tabular}

Примечание. R - резистентные штаммы; I — штаммы, умеренно резистентные (с промежуточной устойчивостью); R+l — нечувствительные штаммы; $\mathrm{S}$ - чувствительные штаммы; - исследование не проводилось. Зеленым цветом отмечены ячейки с низким (менее 3-5\%) уровнем показателя не чувствительных к АМП штаммов N. gonorrhoeae; желтым цветом — ячейки с высоким (более 5\%) уровнем показателя не чувствительных к АМП штаммов N. gonorrhoeae.

в 2006-2009 гг. до 15,4-16,0\% в 2010-2011 гг.). Единственным АМП, к которому все штаммы N. gonorrhoeae, циркулирующие на территории Архангельской области, сохраняли чувствительность на протяжении всех лет наблюдения, был цефтриаксон.

Соотношение процента штаммов N. gonorrhoeae, не чувствительных к АМП, на территории Архангельской области, Российской Федерации в целом и на территории Северо-Западного федерального округа в 2011 г. представлено на рис. 1. Как следует из приведенных данных, процент штаммов N. gonorrhoeae, не чувствительных к АМП, на изучаемых территориях в 2011 г. был сопоставимым (44,0$58,9 \%$ для пенициллина, 55-62,6\% для тетрациклина, $36,0-47,7 \%$ для ципрофллоксацина, 10,3-18,5\% для спектиномицина; 16,0-24,3\% для азитромицина).

В целом следует отметить, что показатели резистентности штаммов N. gonorrhoeae к АМП в Архангельской области в 2011 г. были более низкими, чем по Северо-Западному федеральному округу в целом. Так, процент штаммов N. gonorrhoeae, не чувствительных к пенициллину, тетрациклину, ципрофлоксацину и азитромицину, в Архангельской области был ниже, чем в Северо-Западном фредеральном округе. Исключение составил показатель резистентности штаммов N. gonorrhoeae к спектиномицину: в Архангельской области процент штаммов, не чувствительных к спектиномицину, был в 1,7 раза выше, чем в Северо-Западном федеральном округе.

Существенных различий в показателях чувствительности штаммов N. gonorrhoeae к АМП в зависимости от территорий области (дифференцированно оценивались показатели чувствительности N. gonorrhoeae к АМП в больших группах штаммов, полученных из Архангельска, Северодвинска и Котласа) установлено не было.

В последние годы учеными, занимающимися вопросами изучения резистентности N.gonorrhoeae к АМП, существенное внимание уделяется развитию резистентности $N$.gonorrhoeae к цефалоспоринам III поколения, которые на настоящий момент являются препаратами выбора для лечения гонококковой инфекции $[13,14]$. Первые описания штаммов N. gonorrhoeae со сниженной чувствительностью к цефалоспоринам III поколения относятся к 2001-2003 гг. [15, 16]. В 2011 г. впервые получен штамм N. gonorrhoeae, высокорезистентный к цефралоспоринам III поколения (МИК = = 2-4 мг/л, Киото, Япония) [17]. Учитывая темпы роста антибиотикорезистентности $N$.gonorrhoeae к другим АМП, для развития резистентности N. gonorrhoeae к цефалоспоринам достаточно одного-двух десятилетий. На этом основании можно предполагать, что уже в 2021 г. гонорея может оказаться неизлечимым заболеванием.

Изучение динамики минимальной подавляющей концентрации (МПК) цефтриаксона в отношении штаммов N. gonorrhoeae, циркулировавших на территории Архангельской области в 2006-2011 гг., показало, что количество штаммов с признаками снижения чувствительности к цефтриаксону (МПК выше 0,032-0,064 мкг/мл) на протяжении данного периода составляло 6-10\% (рис. 2).

Сопоставление значений МПК цефтриаксона в отношении штаммов N. gonorrhoeae, циркулировав- 


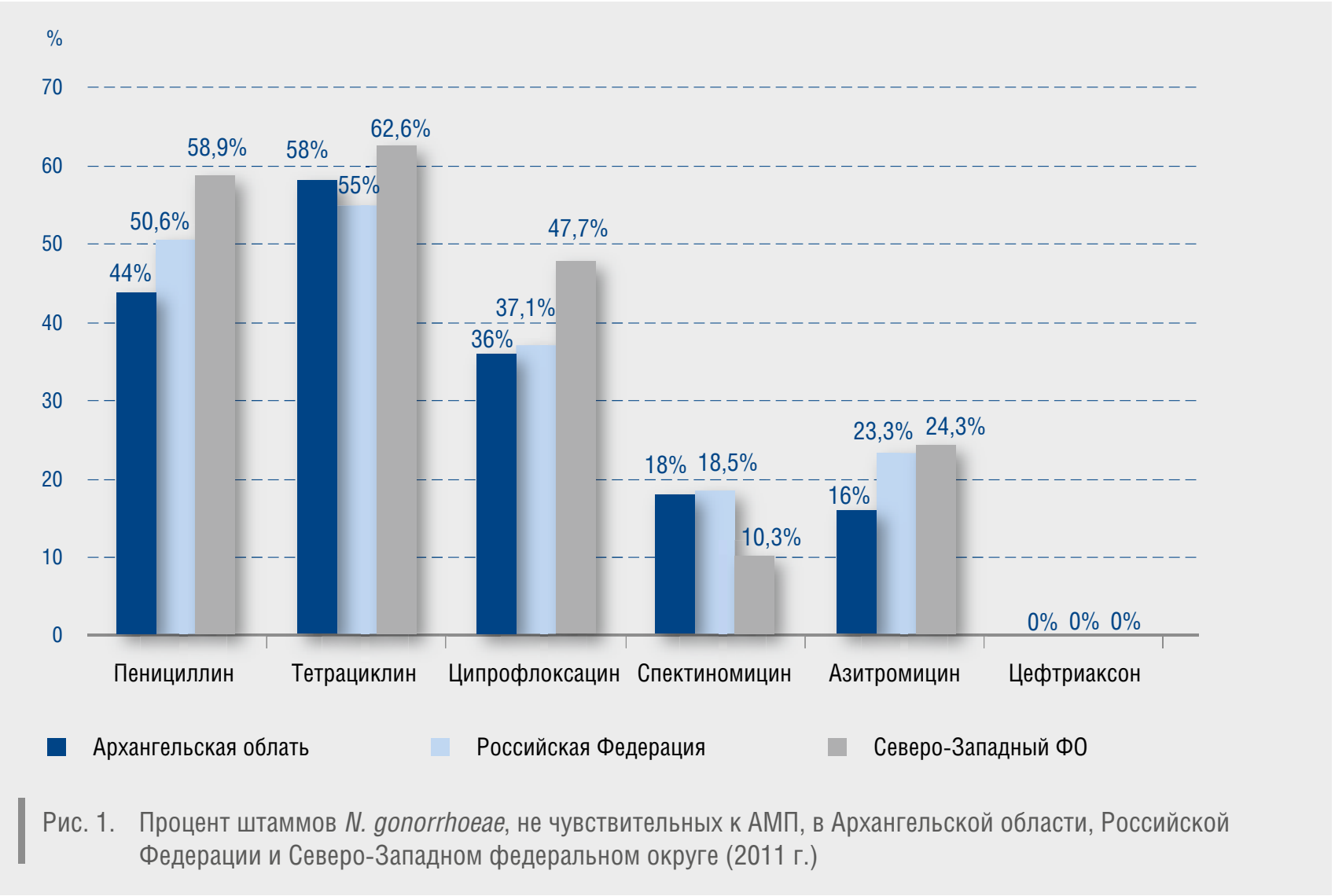

ших на территории Архангельской области, и штаммов, полученных ГНЦДК из различных территорий Российской Федерации, проведенное по данным 2011 г., показало, что в Архангельской области количество штаммов N. gonorrhoeae MПК выше 0,0320,064 мкг/мл было в 2 раза больше (12\%), чем в Российской Федерации в целом (6\%) (рис. 3).

Полученные данные позволяют расценивать ситуацию по антибиотикорезистентности N. gonorrhoeae в Архангельской области как неблагополучную. На территории Архангельской области отмечается высокий процент штаммов N. gonorrhoeae, не чувствительных к пенициллину, тетрациклину и ципрофлоксацину, регистрируется достаточно высокий процент штаммов N. gonorrhoeae, не чувствительных к спектиномицину и азитромицину, существенно превышающий уровень, рекомендуемый ВОЗ для назначения этих АМП [18]. Препаратом для лечения гонококковой инфекции на территории области остается цефтриаксон, к которому сохраняют чувствительность все штаммы N. gonorrhoeae, полученные от больных гонококковой инфекцией на территории области. Однако с учетом появления признаков фрормирующейся устойчивости штаммов N. gonorrhoeae к данному АМП на территории области необходима разработка дополнительной системы мер, направленных на предотвра- щение распространения гонококковой инфекции и резистентных к цефтриаксону штаммов $N$. gonorrhoeae.

Результаты изучения штаммов N.gonorrhoeae методами молекулярной эпидемиологии. Методом NG-MAST на территории Архангельской области было выявлено 29 вариантов сиквенс-типов штаммов N. gonorrhoeae, в том числе 18 (78,4\%) ранее зарегистрированных и 11 (21,6\%) новых, представленных новыми комбинациями известных аллелей и неизвестными аллелями por и tbp генов. Сведения о новых сиквенс-типах были переданы в Международную базу NG-MAST, где им были присвоены международные номера.

В выборке штаммов N. gonorrhoeae Архангельской области преобладали штаммы, представленные единичными сиквенс-типами (21 сиквенс-тип; 72,4\%), что свидетельствовало о значительной гетерогенности выборки. Доминирующими (повторяющимися) оказались $8(27,6 \%)$ сиквенс-типов, в том числе: сиквенс-тип № $343(n=8)$, №5042 ( $n=4)$, № $1523(n=3)$, № 1152 ( $n=3$ ); сиквенс-типы №387, 6238, 5825, 6234 встречались в двух повторах.

При сопоставлении результатов молекулярного типирования штаммов N. gonorrhoeae, полученных от больных гонококковой инфекцией в Архангельской области и в Российской Федерации в целом (данные ГНЦДК, 2011 г.), был установлен ряд общих сиквенс- 


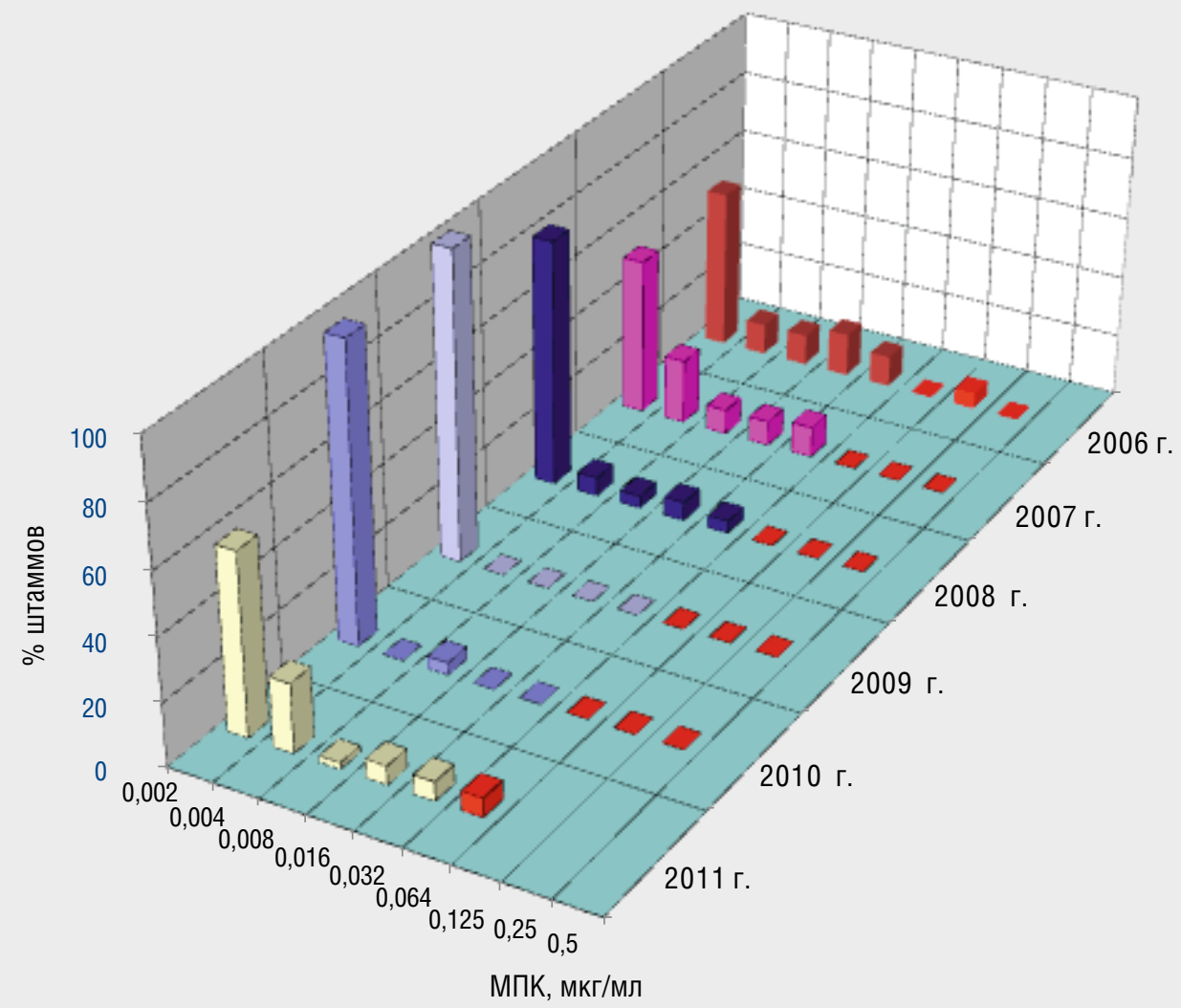

Рис. 2. Распределение МПК цесртриаксона среди штаммов N. gonorrhoeae (Архангельская область, 2006-2011 гг.)

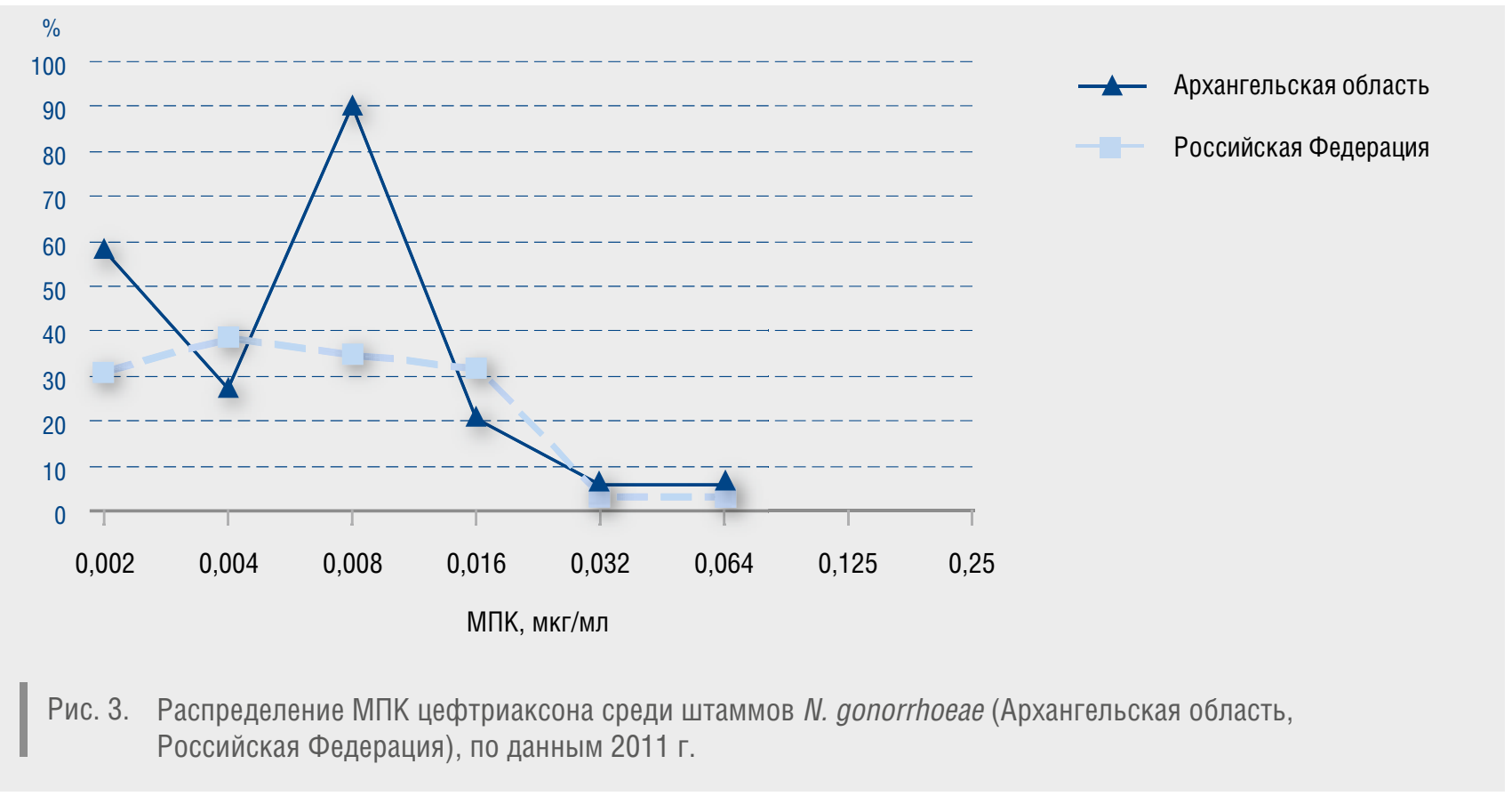




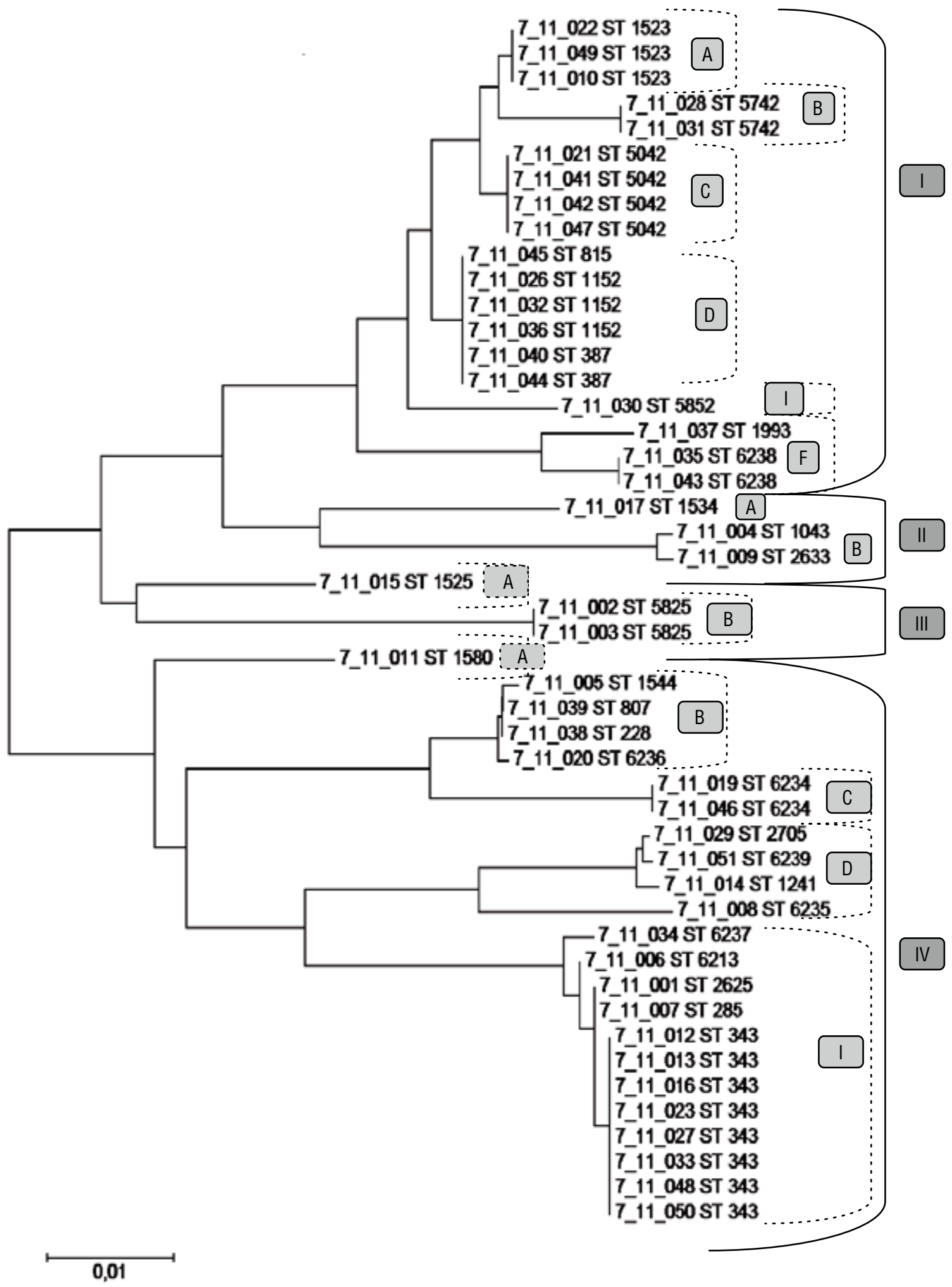


типов N. gonorrhoeae (№228, 285, 807, 1241, 2633), распространенных не только на других территориях Российской Федерации (в Центральном, Южном, Приволжском, Северо-Кавказском, Сибирском, Уральском федеральных округах), но и в других странах мира, в частности в Греции, Великобритании, Германии, Франции, что свидетельствовало о возможности интродукции данных штаммов из других регионов России и из-за рубежа вследствие активной миграции населения (командировки, туризм, трудовая миграция). Вместе с тем доминирующие сиквенс-типы (№343, 5042, 1523, 1152, 387, 6238, 5825, 6234), а также единичные сиквенс-типы оказались уникальными и характерными только для Архангельской области.

Филогенетический анализ штаммов N.gonorrhoeae, полученных от больных гонококковой инфекцией в Архангельской области, позволил выявить два крупных кластера (кластеры I, IV), которые подразделялись на субкластеры (первый - на субкластеры A, B, C, D, I, F; второй - на субкластеры A, B, C, D, I), а также два более мелких кластера (кластеры II, III, каждый из которых включал по два субкластера); все кластеры эволюционно были незначительно удалены друг от друга (эволюционное расстояние 0,01), что свидетельствовало о высокой скорости генетической изменчивости штаммов N. gonorrhoeae (рис. 4).

В крупных кластерах выявлялись сиквенс-типы штаммов N. gonorrhoeae, полученных из разных территорий Архангельской области; выделялись также кластеры, сфрормированные сиквенс-типами, которые были распространены на географически близких территориях Архангельской области, например сиквенс-типы № 1523, 5742 (Архангельск), 5042 (Северодвинск), что свидетельствовало об активном обмене штаммами N. gonorrhoeae между территориями области, которые вместе формировали общий пул штаммов N. gonorrhoeae.

Ряд штаммов $N$.gonorrhoeae с одинаковыми сиквенс-типами (№343: штаммы 7_11_012 ST 343, 7_11_013 ST 343; №5825: штаммы 7_11_002 ST 5825, 7_11_003 ST 5825; № 5042: штаммы 7_11_041 ST 5042, 7_11_042 ST 5042) были получены от половых партнеров, страдавших гонококковой инфекцией. Данное обстоятельство послужило основанием для разработки «Способа молекулярной идентификации источника заражения и/или половых партнеров, больных гонококковой инфекцией» (заявка на патент №2013102160 от 18.01.2013 г.). Способ достигается за счет того, что у больного гонококковой инфекцией (или лица с подозрением на наличие гонококковой инфекции) стандартным способом получают биологический материал, доставляют его в лабораторию, стандартным методом выделяют ДНК, методом ПЦР подтверждают наличие в биологическом образце ДНК N. gonorrhoeae, после чего методом секвенирования проводят исследование вариабельных участков генов
porB и tbpB N. gonorrhoeae и определяют индивидуальный сиквенс-тип штамма $N$. gonorrhoeae, вызвавшего инфекцию. Совпадение сиквенс-типов штаммов N. gonorrhoeae, выделенных у половых партнеров (при наличии эпидемиологических данных об имевшем место половом контакте пациентов), позволяет выявить источник заражения и/или половых партнеров, больных гонококковой инфекцией. Использование предлагаемого способа существенно повышает точность идентификации источника заражения гонококковой инфекцией, так как при этом не только подтверждается (методом ПЦР) принадлежность возбудителя к виду N. gonorrhoeae, но и определяется его сиквенс-тип индивидуальная молекулярно-генетическая характеристика микроорганизма.

Изобретение может быть использовано:

в дерматовенерологии для выявления источника заражения и/или половых партнеров больного гонококковой инфекцией;

в молекулярной эпидемиологии - при необходимости выявления эпидемиологических цепочек распространения заболевания на определенных географических территориях;

в судебно-медицинской экспертизе с целью идентифрикации источника заражения гонококковой инфекцией.

В целях выявления возможной взаимосвязи молекулярных типов $N$. gonorrhoeae и показателей антибиотикорезистентности был проведен анализ ассоциаций между принадлежностью штаммов N. gonorrhoeae к тому или иному кластеру и наличием мультирезистентности. Мультирезистентными считали штаммы N. gonorrhoeae, у которых по данным фенотипического исследования чувствительности к АМП определялась резистентность не менее чем к двум АМП.

В результате проведенного анализа была установлена относительно невысокая частота выявления мультирезистентных штаммов $N$. gonorrhoeae в кластерах I-III, объединявших 25 штаммов N. gonorrhoeae, - 16,0\% (4 из 25) и довольно высокая частота регистрации мультирезистентных штаммов N. gonorrhoeae в кластере IV, в состав которого входили 23 штамма N. gonorrhoeae, - 43,5\% (10 из 23).

Разница в частоте выявления мультирезистентных штаммов $N$. gonorrhoeae в данных группах штаммов была статистически достоверной (OR = 4,0 0 2,8 (1-sigma error bar); $95 \%$ confidence band $=-1,4 ; 9,5$; Pearson $\left.\mathrm{X}^{2}=4.4 ; p=0,036\right)$.

Более подробный анализ распределения мультирезистентных штаммов $N$. gonorrhoeae в составе IV кластера показал, что абсолютное большинство (9 из 12) мультирезистентных штаммов N. gonorrhoeae регистрировалось в составе субкластера І. Различия в частоте встречаемости мультирезистентных штаммов $N$. gonorrhoeae в составе субкластера I кластера IV - 75\% (9 из 12) и в объединенной группе класте- 
ров I-III и субкластеров A-D кластера IV - 13,8\% (5 из 36) оказались высокодостоверными (OR = 18,6 \pm $\pm 5,3$ (1-sigma error bar); $95 \%$ confidence band $=-11,4$; 48,6; Pearson $\left.x^{2}=16,3 ; p<0,001\right)$. Примечательно, что среди мультирезистентных штаммов $N$. gonorrhoeae, входивших в состав субкластера I кластера IV, регистрировались эволюционно близкие сиквенс-типы: № 343, 285, 2625, 6237 .

Полученные результаты свидетельствуют о том, что принадлежность штаммов $N$. gonorrhoeae к определенному кластеру и/или сиквенс-типу, установленная с использованием молекулярных методов, может являться дополнительным молекулярным маркером их мультирезистентности.

Выявление у больных гонококковой инфекцией в Архангельской области потенциально мультирезистентных штаммов N. gonorrhoeae, относящихся к сиквенс-типам №343, 285, 2625, 6237, должно настораживать врачей в отношении возможных трудностей ведения таких пациентов, требует проведения тщательного обследования и определения тактики терапии.

\section{Заключение}

Таким образом, данные, полученные в результате изучения показателей антибиотикорезистентности штаммов N. gonorrhoeae на территории Архангельской области, свидетельствуют о том, что тенденции распространения штаммов N. gonorrhoeae, не чувствительных к АМП, совпадают с общероссийскими. Это дает основание в полной мере распространить клинические рекомендации Российского общества дерматовенерологов и косметологов по выбору препаратов для лечения гонореи на Архангельскую область. Высокий уровень резистентности штаммов N. gonorrhoeae практически ко всем АМП (кроме цефтриаксона) позволяет рекомендовать их исключение из схем терапии гонококковой инфекции на территории Архангельской области. Препаратом для лечения гонококковой инфекции на территории области остается цестриаксон, к которому сохраняют чувствительность все штаммы N. gonorrhoeae, полученные от больных гонококковой инфекцией на территории области.

Результаты молекулярного типирования и филогенетического анализа штаммов N.gonorrhoeae, проведенного с использованием метода NG-MAST и построения дендрограммы, свидетельствуют о значительной гетерогенности выборки штаммов N. gonorrhoeae, циркулирующих на территории Архангельской области, и о высокой скорости их генетической изменчивости. Наличие общих сиквенс-типов штаммов N. gonorrhoeae свидетельствует об активной интродукции штаммов из других территорий Российской Федерации и стран мира вследствие миграции населения. Вместе с тем на территории Архангельской области регистрируются штаммы N. gonorrhoeae, уникальные для данного географического региона (доминирую- щие сиквенс-типы №343, 5042, 1523, 1152, 387, 6238, 5825, 6234, а также единичные сиквенс-типы).

В результате проведенных исследований показана возможность использования молекулярных методов (ПЦР и секвенирования) для индивидуальной идентифрикации источников заражения и половых партнеров больных гонококковой инфекцией и осуществления эпидемиологического мониторинга.

Установлены ассоциации между принадлежностью штаммов N. gonorrhoeae, выделенных от больных гонококковой инфекцией в Архангельской области, к сиквенс-типам №343, 285, 2625, 6237 и их мультирезистентностью, что требует проведения тщательного обследования и определения тактики терапии таких пациентов.

Учитывая высокий уровень заболеваемости гонококковой инфекцией на территории Архангельской области (по данным 2011 г. - 78,8 на 100000 населения), наличие признаков формирующейся устойчивости штаммов N. gonorrhoeae к цефалоспоринам III поколения, возможности молекулярных исследований, методы контроля над распространением гонококковой инфекции на территории Архангельской области должны быть направлены:

на осуществление первичной и вторичной профрилактики распространения гонококковой инфрекции, в том числе путем пропаганды безопасного секса, осуществления эффективного скрининга на наличие гонококковой инфекции в группах риска [19], активного выявления (в том числе молекулярными методами с определением индивидуальных сиквенстипов N. gonorrhoeae) половых партнеров больных для проведения их обследования и лечения;

на отслеживание эпидемиологических цепочек распространения заболевания с использованием молекулярных методов диагностики (ПЦР и секвенирования);

на регулярное отслеживание и учет случаев неудач лечения гонококковой инфекции, в том числе цесралоспоринами III поколения;

на оптимизацию диагностики гонококковой инфекции путем модернизации лабораторий медицинских организаций области, оказывающих помощь больным ИППП (оснащения современным оборудованием, активного внедрения в практику культуральной и молекулярной диагностики, в том числе ПЦР, а в ГБУЗ АО «АККВД» - и секвенирования, регулярного повышения квалификации персонала, обследования населения отдаленных районов области на наличие гонококковой инфекции и других ИППП);

- на регулярное проведение мероприятий по региональному (на уровне Архангельской области) мониторингу антибиотикорезистентности N. gonorrhoeae с обязательным определением чувствительности штаммов N.gonorrhoeae к цефалоспоринам III поколения и индивидуальных сиквенс-типов N. gonorrhoeae. 


\section{Литература}

1. Resursy i deyatel'nost' meditsinskikh organizatsiy dermato-venerologicheskogo profilya. Zabolevaemost' infektsiyami, peredavaemymi polovym putem, zaraznymi kozhnymi boleznyami i boleznyami kozhi za 2010 —2011 gody (statisticheskie materialy). 2012; 236. [Ресурсы и деятельность медицинских организаций дерматовенерологического профиля. Заболеваемость инсекциями, передаваемыми половым путем, заразными кожными болезнями и болезнями кожи за 2010-2011 гг. (статистические материалы). М, 2012; 236.]

2. Kubanova A.A. i dr. Rezistetnost' vozbuditeley IPPP k antimikrobnym preparatam: Inform. byulleten', 2008. M.: 000 «DEKS-PRESS», 2008; 40. [Кубанова А.А. и др. Резистетность возбудителей ИППП к антимикробным препаратам: Информ. бюллетень, 2008. М: 000 «ДЭКСПРЕСС» 2008; 40.]

3. Kubanova A.A. i dr. Rezistentnost' vozbuditeley IPPP k antibakterial'nym preparatam: Inform. byulleten' 2009 god. M.: FGU «GNTsD Minzdravsotsrazvitiya», 2010. 40 s. [Кубанова А.А. и др. Резистентность возбудителей ИППП к антибактериальным препаратам: Информ. бюллетень, 2009 г. М: ФГУ «ГНЦД Минздравсоцразвития» 2010; 40.]

4. Kubanova A., Frigo N., Kubanov A., Sidorenko S., Lesnaya I., Polevshikova S., Solomka V., Bukanov N., Domeika M., M. Unemo. The Russian gonococcal antimicrobial susceptibility programme (RU-GASP) - national resistance prevalence in 2007 and 2008, and trends during 2005-2008. Eurosurveillance April 2010; 5; 8: $10-15$.

5. Bogun A.G., Shemyakin I.G., Stepanshina V.N. Kompleksnoe issledovanie klinicheskikh izolyatov Mycobacterium tuberculosis molekulyarnogeneticheskimi metodami. Materialy konferentsii Federal'noy sluzhby po nadzoru v sfere zashchity prav potrebiteley i blagopoluchiya cheloveka "Biologicheskaya bezopasnost' v sovremennom mire" (21-22 aprelya 2009, FGUN GNTsPMB, Obolensk). S. 47-49. [Богун А.Г., Шемякин И.Г., Степаншина В.Н. Комплексное исследование клинических изолятов Mycobacterium tuberculosis молекулярно-генетическими методами. Материалы конференции Феде- ральной службы по надзору в сфрере защиты прав потребителей и благополучия человека «Биологическая безопасность в современном мире» (21-22 апреля 2009, ФГУН ГНЦПМБ, Оболенск). С. $47-49$.

6. Unemo M., Dillon J.A. Review and international recommendation of methods for typing Neisseria gonorrhoeae isolates and their implications for improved knowledge of gonococcal epidemiology, treatment, and biology. Clin Microbiol Rev 2011; 24(3): $447-458$.

7. Unemo M., Vorobieva V., Firsova N., Ababkova T., Leniv I., Haldorsen B.C., Fredlund H. and Skogen V. Neisseria gonorrhoeae population in Arkhangelsk, Russia: phenotypic and genotypic heterogeneity. Journal Compilation Clinical Microbiology and Infection 2007; 13: 9: 873—878.

8. Manual of antimicrobial susceptibility testing / Stephen J. Cavalieri et al.. American Society for Microbiology 2005; Performance Standards for Antimicrobial Susceptibility Testing $\$$ Seventeenth Informational Supplement. January 2007 M100S17 Vol. 27 No. 1 Replaces M100-S16 Vol. 26 No. 3 Performance: 177

9. The European Committee on Antimicrobial Susceptibility Testing. Breakpoint tables for interpretation of MICs and zone diameters. Version 3.1, 2013. http://www.eucast.org

10. Saitou N., Nei M. The neighbor-joining method: a new method for reconstructing phylogenetic trees. Molecular Biology and Evolution July 1987; 4: 4: 406-425.

11. Xavier Didelot (2010). Sequence-Based Analysis of Bacterial Population Structures. In D. Ashley Robinson, Daniel Falush, Edward J. Feil. Bacterial Population Genetics in Infectious Disease. John Wiley and Sons. P. 46-47. ISBN 978-0-47042474-2.

12. Solomka V.S., Chuprov-Netochin R.N., Frigo N.V., Kubanov A. Experience of molecular typing and phylogenetic analysis of $\mathrm{N}$. gonorrhoeae strains in the Russian Federation. Vestn dermatol I venerol 2012; 2: 13-20. [Соломка В.С., Чупров-Неточин Р.Н., Фриго Н.В., Кубанов А.А. Опыт молекулярного типирования и филогенетического анализа штаммов N. gonorrhoeae в Российской Федерации. Вестн дерматол и венерол 2012; 2: 13-20.]
13. Jakopanec I., Borgen K., Aavitsland P. The epidemiology of gonorrhoea in Norway, 1993-2007: past victories, future challenges. BMC Infectious Diseases 2009; 9: 3.

14. Tomberg J., Unemo M., Davies C., Nicholas R.A. Molecular and structural analysis of mosaic variants of penicillin-binding protein 2 conferring decreased susceptibility to expanded-spectrum cephalosporins in Neisseria gonorrhoeae: role of epistatic mutations Biochemistry. 12 August 2010.

15. Wang S.A., Lee M.V., O'Connor N., Iverson C.J., Ohye R.G., Whiticar P.M.Hale J.A., Trees D.L., Knapp J.S.,. Effler P.V., Weinstock H.S. Multidrugresistant Neisseria gonorrhoeae with decreased susceptibility to cefixime. Hawaii, 2001 Clin Infect Dis. 2003 Sep 15; 37 (6): 849—852.

16. Muratani T, Akasaka S, Kobayashi T, et al. Outbreak of cefozopran (penicillin, oral cephems, and aztreonam) - resistant Neisseria gonorrhoeae in Japan. Antimicrob Agents Chemother 2001; 45: 3603-6.

17. Makoto Ohnishi, Daniel Golparian, Ken Shimuta, Takeshi Saika, Shinji Hoshina, Kazuhiro Iwasaku, Shu-ichi Nakayama, Jo Kitawaki, and Magnus Unemo. Is Neisseria gonorrhoeae Initiating a Future Era of Untreatable Gonorrhea.: Detailed Characterization of the First Strain with High-Level Resistance to Ceftriaxone. Antimicrobial Agents And Chemotherapy July 2011; 55: 73538-3545.

18. World Health Organization. STD Treatment Strategies. Geneva: WHO, 1989: $30 \mathrm{p}$.

19. Baryshkov K.V., Prib I.D., Frigo N.V., Solomka V.S. Epidemiological aspects of gonococcal infection in the arkhangelsk region. Vestnik dermatologii I venerologii 2013; 3: 37-46. [Барышков К.В., Приб И.Д., Фриго Н.В., Соломка В.С. Эпидемиологические аспекты заболеваемости гонококковой инфекцией в Архангельской области. Вестн дерматол и венерол 2013; 3: 37—46.]

об авторах:

К.В. Барышков — главный врач ГБУЗ АО «Архангельский клинический кожно-венерологический диспансер»

Н.В. Фриго - Д.м.н., зам. директора по научно-образовательной работе ФГБУ «ГНЦДК» Минздрава России, Москва

В.С. Соломка - к.б.н., ведущий научный сотрудник научной части ФГБУ «ГНЦДК» Минздрава России, Москва 